\title{
Pendidikan Lingkungan pada Mata Kuliah Pendukung Pemanfaatan Kebun Percobaan di Jurusan Biologi
}

\author{
Andi Faridah Arsal ${ }^{1}$, Gufron D.Dirawan ${ }^{2}$, Yusminah Hala ${ }^{1}$, Suradi Tahmir ${ }^{3}$ \\ ${ }^{1}$ Program studi Biologi, Fakultas Matematika dan Ilmu Pengetahuan Alam \\ Universitas Negeri Makassar \\ "Email: a.faridaharsal@gmail.com \\ ${ }^{2}$ Program Studi Pendidikan Kependudukan dan Lingkungan Hidup \\ Pascasarjana Universitas Negeri Makassar \\ ${ }^{3}$ Program Studi Matematika, Fakultas Matematika dan Ilmu Pengetahuan Alam \\ Pascasarjana Universitas Negeri Makassar
}

(c) 2018 - UEJ Program Studi Pendidikan Kependudukan dan Lingkungan Hidup Universitas Negeri Makassar.
Ini adalah artikel dengan akses terbuka dibawah Licensi CC BY-NC-4.0
(http:/creativecommons.org/licenses/by-nc/4.0)

\begin{abstract}
This study aims: (1). To identify the main support system in the design of environmentbased learning in the Department of Biology, Faculty of Mathematics and Natural Sciences, Makassar State University. (2). Knowing the use of environment-based learning resources in the Department of Biology, Faculty of Mathematics and Natural Sciences, Makassar State University. Through the Needs Assessment instrument in the form of field observations, questionnaire surveys, and interviews with lecturers and students identified problems to determine the right action for the next stage, so the design of learning to be carried out is the best solution. The results of the study are that (1). The Biology Department of UNM has two main locations or areas that strongly support environmentbased learning with their respective characteristics. The two areas are the Biology Experiment Garden and the Field of Library Discussion of the Biology Department of FMIPA UNM. (2) Some courses have made use of environment-based learning resources in the Biology Department of FMIPA UNM. Solutions from the identification results obtained are among others; (1). The Department of Biology can be used as a place of learning, a source of learning, and as a learning media in the design of environmentbased learning. (2). The Biology Department can be used as a comfortable and pleasant learning environment for the entire academic community. (3). The design of Environmental Based Learning in the Biology Department of UNM can be done in almost all subjects by increasing the role of the lecturer as a facilitator.
\end{abstract}

Keywords: Needs Analysis, Learning, Learning Resources, Environment, Biology

\section{PENDAHULUAN}

Pengembangan model pembelajaran berbasis lingkungan di perguruan tinggi dapat dicapai sesuai pendidikan menurut UU No. 20 Tahun 2003 yakni; "Pendidikan adalah usaha sadar dan terencana untuk mewujudkan suasana belajar dan proses pembelajaran agar peserta didik secara aktif mengembangkan potensi dirinya untuk memiliki kekuatan spiritual keagamaan, pengendalian diri, kepribadian, kecerdasan, akhlak mulia, serta keterampilan yang diperlukan dirinya, masyarakat, bangsa dan Negara" (Afandi 2013).

Empat pilar pendidikan yakni learning to know (belajar untuk mengetahui), learning to be (belajar untuk menjadi jati dirinya), learning to do (Belajar untuk mengerjakan sesuatu) dan learning to life together (belajar untuk bekerja sama) dapat dilakukan sekaligus dalam pembelajaran berbasis lingkungan (Kristiawan dkk. 2017). Menurut Dewey sehubungan dengan teori pendidikannya menyatakan bahwa alam dan sesama manusia berperan dalam proses pembentukan kecakapan fundamental secara intelektual dan emosional. Sesuai dengan fakta ekspresi gen bahwa lingkungan- 
baik lingkungan internal maupun eksternal- amat berperan membuat suatu gen bekerja tidak maksimal, dapat pula membuat suatu gen bekerja atau tidak sama sekali (Musta'in 2016). Dengan demikian perlunya desain pembelajaran berbasis lingkungan khususnya di Jurusan Biologi Fakultas Matematika dan Ilmu Pengetahuan Alam Universitas Negeri Makassar. Turut berperan mendukung visi Program Studi Biologi Fakultas Matematika dan Ilmu Pengetahuan Alam Universitas Negeri Makassar. Visi Program Studi Biologi: "Menjadi program studi yang handal dalam pembelajaran, pengkajian, pengembangan dan penelitian Biologi pada tahun 2020 berdasarkan imtaq, serta berdaya guna secara maksimal bagi agama, masyarakat, bangsa, dan negara".

Pendidikan lingkungan di Jurusan Biologi secara tidak langsung terintegrasi dalam hampir seluruh mata kuliah pendukung. Mempelajari masalah tanaman, hewan, bahkan masalah ekologi secara tak langsung terkait pendidikan lingkungan. Sehingga tidak sulit memunculkan sikap peduli lingkungan pada mahasiswa Jurusan Biologi.

Pembelajaran berbasis lingkungan yang akan dikembangkan merupakan; (1). model pembelajaran yang memanfaatkan lingkungan secara maksimal sebagai pembiasaan dan pencapaian tujuan belajar (Ali dkk. 2018). Pembelajaran yang memanfaatkan lingkungan sebagai sumber belajar. Pembelajaran yang memanfaatkan lingkungan sebagai tempat belajar (Lingkungan yang asri seperti taman yang rindang dilengkapi sarana dan nuansa yang nyaman dapat menjadi lingkungan belajar yang nyaman dan menyenangkan dalam belajar). Pembelajaran yang memanfaatkan lingkungan sebagai media, yakni dengan memanfaatkan bahan-bahan yang ada di sekitar sebagai media pembelajaran, karena Konsep-konsep sains dapat dengan mudah dikuasai melalui pengamatan pada situasi yang konkret. (2). Pengkondisian situasi belajar dalam usaha pencapaian perubahan tingkah laku yang diharapkan, memunculkan dan meningkatkan sikap tanggung jawab terhadap lingkungan sekitar (peduli lingkungan).

Pembelajaran Berbasis Lingkungan di perguruan tinggi penting dilakukan sebagai pembiasaan terhadap lingkungan dan peningkatan kognitif pada mahasiswa. Pembiasaan yang dilakukan ini akan memunculkan kepedulian terhadap lingkungan (Haris dkk. 2018). Untuk itu diperlukan Analisa kebutuhan pembelajaran atau need assestmen. Need assestmen perlu dilakukan guna mengetahui terpenuhinya sistem pendukung utama pembelajaran berbasis lingkungan. Sistem pendukung utama pembelajaran berbasis lingkungan selain berperan sebagai lingkungan belajar juga sebagai sumber belajar.

Adapun tujuan dari penelitian ini adalah (1). Mengidentifikasi sistem pendukung utama dalam desain pembelajaran berbasis lingkungan di Jurusan Biologi Fakultas Matematika dan Ilmu Pengetahuan Alam Universitas Negeri Makassar dan (2). Mengetahui pemanfaatkan sumber belajar berbasis lingkungan di Jurusan Biologi Fakultas Matematika dan Ilmu Pengetahuan Alam Universitas Negeri Makassar.

\section{METODE}

Penelitian ini menggunakan pendekatan kualitatif. Penelitian kualitatif merupakan metodemetode untuk mengeksplorasi suatu hal yang dianggap berkaitan dengan masalah sosial (Creswell dan Clark 2017). Jenis penelitian ini adalah studi kasus. Pada tahapan analisis kebutuhan ini dikumpulkan informasi menggunakan Survey Kuisoner, observasi, dan wawancara.

Teknik Analisa Data menggunakan model interaktif Miles \& Hubberman dalam Gunawan (2013) yaitu reduksi data, penyajian data, dan menarik kesimpulan. 
UNM Environmental Journals, Vol. 2 No. 1 Desember 2018 hal. 1 - 5

\section{HASIL DAN PEMBAHASAN}

\section{Hasil}

Berdasarkan hasil observasi, survey dan wawancara di Jurusan Biologi, seluruh mata kuliah pendukung konsep Biologi telah tersirat pendidikan lingkungan. Secara tidak langsung mahasiswa telah memperoleh kearifan lingkungan yang dipahami secara ilmiah. Berikut Tabel Pendidikan lingkungan yang terkandung dalam pembahasan materi pada beberapa mata kuliah di Jurusan Biologi

Tabel 4.3 Pendidikan lingkungan yang terkandung dalam pembahasan materi pada beberapa mata

\begin{tabular}{lll}
\multicolumn{3}{c}{ kuliah Jurusan Biologi } \\
\hline NO & \multicolumn{1}{c}{ Mata Kuliah } & \multicolumn{1}{c}{ Materi } \\
\hline 1. & Fisiologi Tumbuhan & Fotosintesis, penguapan, dan biologi sel \\
\hline 2. & Media dan Sumber Belajar Biologi & $\begin{array}{l}\text { Pemanfaatan lingkungan sekitar sebagai } \\
\text { sumber belajar }\end{array}$ \\
\hline 3. & Pendidikan Lingkungan Hidup & Daur ulang limbah atau sampah \\
\hline 4. & Media dan TIK Pembelajaran & Media berbasis lingkungan \\
\hline 5. & Botani Tumbuhan Tingkat Tinggi & Keanekaragaman hayati dan klasifikasi \\
\hline 6. & Ekologi Tumbuhan & Analisis vegetasi \\
\hline 7. & Morfologi Tumbuhan & Bagian vegetatif dan generatif. \\
\hline 8. & Ilmu Gizi & Keamanan pangan \\
\hline 9. & Nutrisi Tumbuhan & "semua topik" \\
\hline 10. & Genetika Molekular & Ekspresi gen \\
\hline 11. & Ekologi Hewan & Predasi \\
\hline 12. & Genetika & \\
\hline
\end{tabular}

Tabel diatas menunjukkan bahwa terdapat materi lingkungan yang terkandung dalam 12 mata kuliah yang terdapat di Jurusan Biologi Fakultas Matematika dan Ilmu Pengetahuan Alam Universitas Negeri Makassar.

\section{Pembahasan}

Sebagaimana konsep pembelajaran berbasis lingkungan yakni outdoor learning dan inquiri, maka pengembangan suatu model pembelajaran berbasis lingkungan mesti mempertimbangkan terpenuhinya sistem pendukung utama. Sistem pendukung utama pada pembelajaran berbasis lingkungan adalah segala sumber daya yang terdapat di lingkungan yang dapat digunakan sebagai sumber belajar dan lingkungan alam sebagai lingkungan belajar. Sistem pendukung utama pembelajaran berbasis lingkungan merupakan potensi yang mesti ada untuk penyelenggaraan model pembelajaran berbasis lingkungan. Jurusan Biologi Fakultas Matematika dan Ilmu Pengetahuan Alam Universitas Negeri Makassar telah memiliki potensi sebagai sistem pendukung utama untuk model pembelajaran berbasis lingkungan. Berdasarkan hasil penelitian terdapat dua area utama yang amat mendukung desain pembelajaran berbasis lingkungan yaitu (1). Kebun Percobaan Biologi dan (2). Pelataran Diskusi Perpustakaan Jurusan Biologi FMIPA UNM.

Kebun Percobaan Biologi FMIPA Universitas Negeri Makassar (UNM) merupakan salah satu bagian penting dari Jurusan Biologi FMIPA UNM. Terletak di seberang jalan bagian selatan gedung Jurusan Biologi FMIPA UNM. Menempati areal seluas 6766,49 $\mathrm{m}^{2}$ memiliki pepohonan rindang di beberapa bagiannya memberikan kondisi teduh dan nyaman dalam kegiatan out learning bagi mahasiswa. Kegiatan menganalisa dan diskusi setelah melakukan eksplorasi dengan observasi secara langsung sangat efektif. Observasi ke objek pembelajaran secara langsung sangat memungkinkan untuk dilakukan. Ratusan jenis koleksi tanaman yang dimiliki dapat berperan sebagai media kongkrit, sebagai sumber belajar yang dimanfaatkan (by utility resources). Demikian pula dengan berbagai koleksi jenis hewan yang terdapat di Kebun Percobaan Biologi dapat menjadi media dan objek langsung dalam memahami beberapa konsep dalam ilmu biologi. Akses internet yang mudah di Kebun 
Percobaan Biologi membuka seluas-luasnya bagi mahasiswa menuju informasi ilmu pengetahuan saat tahapan menganalisa dan diskusi. Berbagai aktivitas positif sebagai refleksi peduli lingkungan yang rutin dilakukan dapat menambah pengetahuan mahasiswa maupun civitas akademika lainnya. Aktivitas positif tersebut berupa pembuatan pupuk cair organik, pupuk kompos, budidaya tanaman, hidroponik, beternak ayam, ikan, dan burung, hingga kegiatan pameran bertajuk Biology Experimental Farm Expo.

Pelataran Diskusi Perpustakaan Jurusan Biologi FMIPA UNM merupakan bagian dari Perpustakaan Jurusan Biologi FMIPA UNM yang disediakan khusus untuk pengunjung yang ingin membaca atau belajar secara kelompok, tanpa mengganggu pengunjung lainnya (SOP Perpustakaan Jurusan Biologi, 2017). Batasan areal Pelataran Diskusi mencakup teras depan, taman sisi kiri dan kanan Perpustakaan Jurusan Biologi FMIPA UNM. Seluruh areal dalam kondisi teduh dan rindang. Terdapat beberapa pohon dan puluhan jenis tanaman. Tersedia beberapa tempat duduk untuk diskusi kelompok. Mahasiswa boleh membawa buku ke areal ini dengan sepengetahuan pengelola perpustakaan. Pemanfaatan dalam outdoor learning sangat memungkinkan. sedangkan pemanfaatannya sebagai sumber belajar tergantung dosen sebagai fasilitator.

Untuk memanfaatkan seluruh potensi yang telah dimiliki oleh Jurusan Biologi FMIPA UNM diperlukan kemampuan khusus dosen sebagai fasilitator. Tidak semua mata kuliah di Jurusan biologi memanfaatkan lingkungan dalam pembelajarannya. Mata kuliah yang telah memanfaatkanpun masih terbatas hanya pada materi tertentu. Satu-satunya mata kuliah yang telah menggunakan lingkungan dalam pembelajarannya untuk semua topik adalah mata kuliah Nutrisi Tumbuhan. Pengembangan model pembelajaran berbasis lingkungan perlu dilakukan. Dengan pembelajaran berbasis lingkungan, mahasiswa akan mengalami pembelajaran bermakna. Menurut teori pembelajaran bermakna dan teori pengolahan informasi bahwa pembelajaran akan diolah menjadi memori jangka panjang jika pembelajaran itu bermakna (Sholahuddin, 2015). "Bisa karena biasa" merupakan ungkapan bijak yang sudah sangat populer dan sederhana, tetapi mengandung kebenaran. Pembiasaan mahasiswa dalam pembelajaran berbasis lingkungan berupa pembiasaan pada situasi alam dan sebagai media kongkrit dalam pembelajaran membuat ketergantungan. Ketergantungan mengakibatkan rasa kebutuhan dan rasa memiliki yang pada akhirnya menyebabkan kepedulian terhadap lingkungan.

Lingkungan yang ada di Kebun Percoobaan Biologi dan di Pelataran Diskusi Perpustakaan Jurusan Biologi FMIPA UNM merupakan sumber belajar yang baik. Terutama dalam mempelajari konsep keanekaragaman Spermatophyta, Morfologi Tumbuhan Tingkat Tinggi karena sejumlah tumbuhan Spermatophyta yang terdapat di lingkungan kedua areal tersebut berjumlah sangat bervariasi dan dapat dijadikan sebagai sumber belajar secara optimal.

Solusi dari hasil identifikasi yang diperoleh adalah antara lain; (1). Jurusan Biologi dapat digunakan sebagai tempat belajar, sumber pembelajaran, dan sebagai media pembelajaran dalam desain pembelajaran berbasis lingkungan. (2). Lingkungan Jurusan Biologi dapat digunakan sebagai lingkungan belajar yang nyaman dan menyenangkan bagi seluruh civitas akademik dalam desain pembelajaran berbasis lingkungan. (3). Desain Pembelajaran Berbasis Lingkungan di Jurusan Biologi UNM dapat dilakukan pada hampir seluruh mata kuliah dengan meningkatkan peran dosen sebagai fasilitator.

\section{KESIMPULAN DAN SARAN}

Adapun kesimpulan dari hasil penelitian ini yaitu Jurusan Biologi UNM memiliki dua lokasi atau area utama yang amat mendukung pembelajaran berbasis lingkungan dengan karakteristiknya masing-masing. Kedua area tersebut adalah Kebun Percobaan Biologi dan Pelataran Diskusi Perpustakaan Jurusan Biologi FMIPA UNM. Sebahagian mata kuliah telah memanfaatkan sumber belajar berbasis lingkungan di Jurusan Biologi FMIPA UNM

Saran dari hasil penelitian ini berupa solusi. Solusi diperoleh dari hasil analisis dari identifikasi masalah. Solusi dari hasil identifikasi yang diperoleh adalah antara lain; (1) Jurusan Biologi dapat digunakan sebagai tempat belajar, sumber pembelajaran, dan sebagai media pembelajaran dalam desain pembelajaran berbasis lingkungan. (2) Lingkungan Jurusan Biologi dapat digunakan sebagai lingkungan belajar yang nyaman dan menyenangkan bagi seluruh civitas akademik 
UNM Environmental Journals, Vol. 2 No. 1 Desember 2018 hal. 1 - 5

dalam desain pembelajaran berbasis lingkungan. dan (3) Desain Pembelajaran Berbasis Lingkungan di Jurusan Biologi UNM dapat dilakukan pada hampir seluruh mata kuliah dengan meningkatkan peran dosen sebagai fasilitator.

\section{REFERENSI}

[1] Afandi, Rifki. 2013. "Integrasi pendidikan lingkungan hidup melalui pembelajaran IPS di sekolah dasar sebagai alternatif menciptakan sekolah hijau." PEDAGOGIA: Jurnal Pendidikan 2(1): 98-108.

[2] Ali, M., Ardi, M. and Tahmir, S., 2018. Penerapan Pendidikan Lingkungan Hidup Di Perguruan Tinggi Dengan Model Outdoor Learning. UNM Environmental Journals, 1(3), pp.77-81.

[3] Creswell, John W., dan Vicki L. Plano Clark. 2017. Designing and conducting mixed methods research. Sage publications.

[4] Gunawan, Imam. 2013. "Metode penelitian kualitatif." Jakarta: Bumi Aksara.

[5] Haris, Risma, Sapto Haryoko, Jasruddin Jasruddin, dan Nurlita Pertiwi. 2018. "Pengetahuan Dan Sikap Mahasiswa Tentang Kewirausahaan Yang Berwawasan Lingkungan Di Perguruan Tinggi." Dalam Seminar Nasional Hasil Penelitian (SNP2M PNUP),

[6] Kristiawan, Muhammad, Syarwani Ahmad, Tobari Tobari, dan Suhono Suhono. 2017. "Desain Pembelajaran SMA Plus Negeri 2 Banyuasin III Berbasis Karakter Di Era Masyarakat Ekonomi ASEAN." Jurnal Iqra': Kajian Ilmu Pendidikan 2(2): 403-432.

[7] Musta'in, Muhammad. 2016. "Pendidikan Berbasis Pengalaman Menurut Pemikiran John Dewey Dan Relevansinya Dalam Pendidikan Islam (TeiAah Buku Experience And Education Penulis John Dewey)." PhD Thesis. Stain Kudus. 